\title{
PENENTUAN KADAR CAPSAICIN MENGGUNAKAN METODE KROMATOGRAFI LAPIS TIPIS (KLT) PADA CABE KATOKKON
}

\author{
Nur Amaliah \\ Politeknik Negeri Balikpapan \\ nur.amaliah@poltekba.ac.id
}

\begin{abstract}
The aims of this research are to determine the best type of solvent based on capsaicin level, the level of capsaicin in green and red katokkon pepper powder in katokkon pepper powder and extract. The research used the analysis of Thin Layer Chromatography (TLC), which is a separation method with absorption on a thin layer of adsorbent. The solvent used to extract capsaicin was ethanol. The highest level of capsaicin was found in red katokkon pepper powder, at a level of 0,304\% ( \pm 0,016). Meanwhile, green katokkon pepper powder contain capsaicin of $0,266 \%$ $( \pm 0,015)$.
\end{abstract}

Keywords : katokkon pepper, Thin Layer Chromatography (TLC), capsaicin level

\begin{abstract}
Abstrak
Penelitian ini bertujuan menentukan jenis pelarut yang terbaik berdasarkan kadar capsaicinnya, mengetahui kadar capsaicin pada buah cabe katokkon berwarna hijau dan berwarna merah dengan perlakuan bubuk dan hasil ekstraksinya pada cabe katokkon. Penelitian ini menggunakan metode kromatografi berupa kromatografi lapis tipis (KLT) yang merupakan cara pemisahan dengan adsorbsi pada lapisan tipis adsorbennya. Pelarut yang digunakan untuk mengekstrak capsaicin yaitu etanol. Hasil penelitian menunjukkan bahwa kadar capsaicin tertinggi terdapat pada bubuk cabe katokkon merah sebesar 0,304\% $( \pm 0,016)$ sedangkan bubuk cabe katokkon hijau sebesar 0,266\% $( \pm$ $0,015)$.
\end{abstract}

Kata kunci : cabe katokkon, Kromatografi Lapis Tipis (KLT), kadar capsaicin

\section{Pendahuluan}

Tanaman cabe termasuk dalam Familia Solanaceae di mana tingkat kepedisan bervariasi tergantung varietas, iklim/cuaca, tempat tumbuh cabe itu sendiri. Dari berbagai jenis cabe yang diperdagangkan di Tana Toraja, ada satu jenis cabe yang menjadi pilihan utama yang dikenal dengan nama cabe Katokkon/kadokkon, dikatakan pilihan utama karena cabe lain baru akan dipilih kalau cabe ini sudah tidak tersedia lagi.Cabe tersebut tergolong ke dalam cabe besar (Capsium annum $L$ ), bentuk buahnya pendek, gemuk dan tumpul, ukuran normalnya sepanjang 3-4 cm dan penampangnya selebar $2-3,5 \mathrm{~cm}$ mirip cabe paprika hanya ukurannya lebih kecil.
Aromanya khas dan rasanya spesifik karena rasa pedasnya sangat terasa.

Buah cabe memiliki senyawa alam yang dapat memberikan manfaat yang sangat besar bagi manusia. Salah satu senyawa yang paling berperan dalam tanaman cabe adalah capsaicin, di mana capsaicin ini merupakan metabolit sekunder dari tanaman cabe. Selain capsaicin, senyawa kimia yang berkaitan dengan metabolit sekunder adalah alkaloid, terpenoid, steroid, saponin, dan lain-lain.

Cabe memiliki rasa yang pedas dan memiliki aroma yang sangat tajam. Yang berperan dalam pemberi rasa pedas pada cabe yaitu senyawa capsaicinoid. Capsaicinoid meliputi nordihydrocapsaicin,capsaicin, 
dihydrocapsaicin,

norcapsaicin,

homodihydrocapsaicin, homocapsaicin, nonivamide [1]. Capsaicin (8-metil- $N$-vanilil6-nonenamida) merupakan komponen aktif cabe yang menghasilkan panas dalam cabe. Capsaicin bersifat iritan terhadap mamalia termasuk manusia, dan menimbulkan rasa terbakar dan panas pada jaringan manapun yang tersentuh. Dalam bidang farmasi selain untuk meredakan rasa sakit atau nyeri, capsaicin juga dikenal memiliki aktivitas antikanker [2]. Capsaicin juga diujicobakan sebagai obat diabetes oleh peneliti asal Toronto, Canada [3]. Capsaicin mempunyai potensi yang tinggi dalam bidang farmasi sebagai anti kanker, anti artritis dan analgesik di samping turut mempunyai nilai komersil dalam industri makanan [4][5][6].

Pada penelitian ini, analisis yang digunakan yaitu analisa kromatografi yang mana dapat memisahkan atau memurnikan kandungan tumbuhan. Pemilihan teknik kromatografi sebagian besar bergantung pada sifat kelarutan dan keatsirian senyawa yang akan dipisah. Jenis Kromatografi yang akan digunakan yaitu Thin Layer Chromatography (TLC) yang merupakan cara pemisahan dengan adsorbsi pada lapisan tipis adsorbennya. Thin Layer Chromatography (TLC) dapat menganalisa senyawa secara kualitatif dan juga kuantitatif.

\section{Metoda Penelitian}

\subsection{Alat dan Bahan}

Alat yang digunakan pada penelitian ini adalah pisau, baskom, ayakan, sendok, neraca digital (digital analytical balance), oven, efendorff, pipet micro, erlenmeyer, labu ukur, camber, TLC densitometri, rotary evaporator, spektro UV-Vis.

Bahan yang digunakan pada penelitian ini adalah cabe katokkon, standar capsaicin, etanol, metanol, toluen, chloroform, hexan, etil asetat, TLC silica gel $60 \mathrm{~F}_{254}$, natrium carbonat, natrium nitrit, aluminium klorid hexahydrate, folin ciocalteus phenol reagen.

\subsection{Metode Penelitian}

\subsubsection{Penentuan Jenis Pelarut}

1. Cabe katokkon hijau dan yang merah dicuci lalu dibelah. Selanjutnya dikeringkan dalam oven pada suhu 45 ${ }^{\circ} \mathrm{C}$ selama 48 jam.

2. Masing-masing cabe katokkon kering kemudian dihaluskan lalu di ayak.

3. Bubuk cabe ditimbang sebanyak 100 mg, lalu dimasukkan kedalam efendorff.

4. Masing-masing cabe bubuk diencerkan dengan hexan, etanol, metanol, chloroform, etil acetat, dan larutan standar.

5. Bahan dihomogenkan menggunakan vortex selama 2 menit lalu didiamkan selama 5 menit.

6. Bahan ditotol sebanyak $20 \mathrm{yL}$ ke lempeng silika gel $60 \mathrm{~F}_{254}$.

7. Lempeng silika yang telah ditotol dimasukkan ke dalam camber yang berisi toluen:kloroform:etanol (45:25:30) $20 \mathrm{ml}$.

8. Setelah cairan sampai pada batas penandaan, lempeng silika dikeringkan selama 5 menit lalu diamati pada lampu visible.

9. Lempeng dimasukkan ke dalam KLT densitometri dengan panjang gelombang 228 .

10. Hasil akan terbaca pada scanner detector.

\subsubsection{Preparasi Sampel Bubuk Cabe}

1. Masing-masing bubuk cabe katokkon ditimbang seberat $\quad 500 \mathrm{mg}$ lalu dimakukkan ke dalam labu ukur.

2. Masing-masing sampel diencerkan menggunakan etanol hingga tanda tera lalu didiamkan selama semalam.

3. Hasil pengenceran ditotolkan pada lempeng silika gel 60 F254 masingmasing sebanyak $10 \mathrm{uL}$ dan standar sebanyak 5, 10, 15, 20, 25 чL.

4. Lempeng silika yang telah ditotol dimasukkan ke dalam camber yang berisi toluene:kloroform:etanol (50:25:25) $20 \mathrm{ml}$.

5. Setelah cairan sampai pada batas penandaan, lempeng silika dikeringkan 
selama 5 menit lalu diamati pada lampu visible.

6. Lempeng dimasukkan ke dalam KLT densitometri dengan panjang gelombang 228 .

7. Hasil akan terbaca pada scanner detector.

\subsubsection{Ekstrasi}

1. Masing-masing bubuk cabe katokkon ditimbang seberat 5 g lalu dimasukkan ke dalam erlenmeyer.

2. Masing-masing bubuk cabe ditambahkan etanol sebanyak $50 \mathrm{ml}$ lalu diamkan selama 2 hari.

3. Hasil pengenceran disaring menggunakan kertas saring.

4. Masing-masing residu yang tertinggal ditambahkan $50 \mathrm{ml}$ etanol lalu distirer selama 30 menit. Perlakuan ini dilakukan sebanyak 2 kali.

5. Hasil pengenceran kemudian diuapkan etanolnya dengan menggunakan rotary evaporator untuk diperoleh hasil ekstraknya.

6. Hasil ekstrak dipindahkan dalam labu takar $10 \mathrm{ml}$ dan ditambahkan etanol hingga tanda tera.

7. Hasil ekstraksi ditotolkan sebanyak 2 ul dan standar sebanyak 5 yl.

8. Lempeng silika yang telah ditotol dimasukkan ke dalam camber yang berisi toluen:kloroform:etanol (50:25:25) $20 \mathrm{ml}$.

9. Setelah cairan sampai pada batas penandaan, lempeng silika dikeringkan selama 5 menit lalu diamati pada lampu visible.

10. Lempeng dimasukkan ke dalam KLT densitometri dengan panjang gelombang 228 .

11. Hasil akan terbaca pada scanner detector.

\subsubsection{Tingkat Kepedisan}

Scoville heat unit (SHU) atau nilai (SHV) konversi:
Tingkat kepedisan cabe diukur dalam satuan Scoville atau nilai yang ditunjuk oleh Scoville (1912) [7] yang dikembangkan secara umum dengan skala Scoville, di mana lada Bell khas dinilai pada 0 - 100 SHV, Habanero pepper 100.000-350.000 SHV sedangkan kapsaisin murni dinilai pada 16 juta SHV [8].

Capsaicinoid dikonversi ke Scoville heat value (SHV) dengan menjumlah berat konsentrasi lada kering capsaicinoid dalam bagian per juta (ppm) dengan koefisien nilai panas untuk setiap senyawa Nordihydrocapsaicin lalu dikali 1,16 untuk Kedua Capsaicin dan Dihydrocapsaicin [9]. SHU total $=[$ CAPS $(\mathrm{ppm})] \times 16,1$

Keterangan : CAPS $=$ Capsaicin

\section{Hasil Penelitian}

\subsection{Penentuan Jenis Pelarut}

Dalam proses pemisahan atau pemurnian bahan alam sangat dibutuhkan pelarut yang dapat memisahkan senyawa yang ingin dianalisa. Pada penelitian ini dilakukan pengujian pelarut organik dengan menggunakan pelarut heksan, etanol, metanol, kloroform, dan etil asetat.Penentuan pelarut pada penelitian ini dimaksudkan untuk mengetahui jenis pelarut apa yang terbaik dalam mengekstrak capsaicin.

Hasil yang diperoleh pada penelitian untuk pengujian jenis pelarut dapat dilihat pada Gambar 1. Pada penelitian digunakan lima jenis pelarut organik yaitu hexane, metanol, etanol, cloroform, dan etil asetat dimana standar capsaicin digunakan sebagai pembanding dalam penentuan kelarutan capsaicin pada cabe. Pada Gambar 1 dapat dilihat bahwa metanol dan etanol merupakan jenis pelarut yang dapat melarutkan capsaicin lebih banyak dari pada jenis pelarut yang lain. 


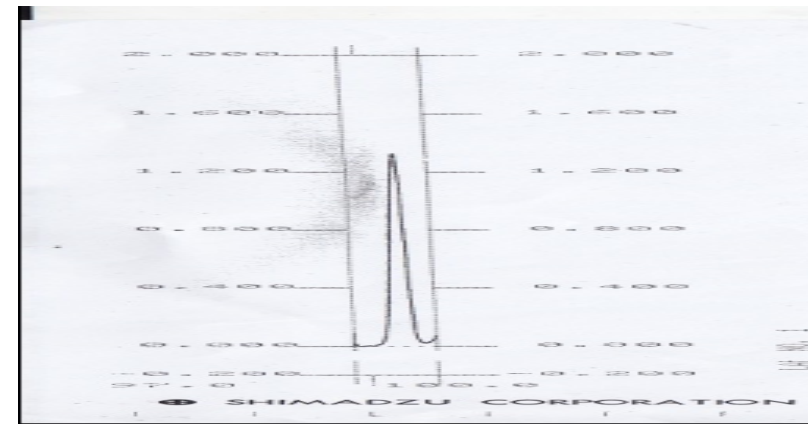

a. Standar

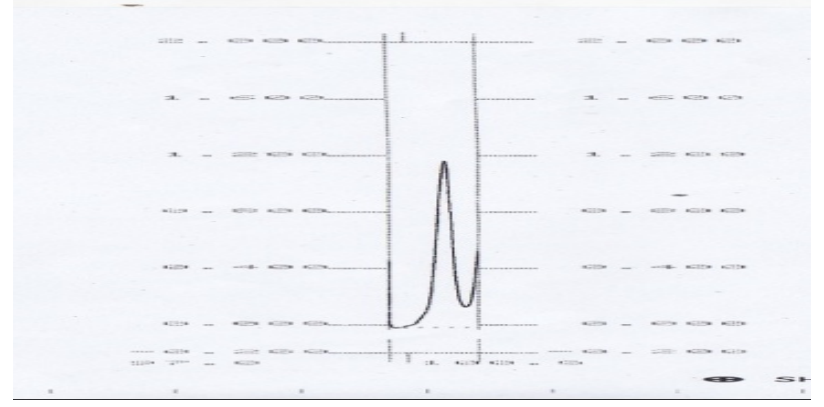

c. Etanol

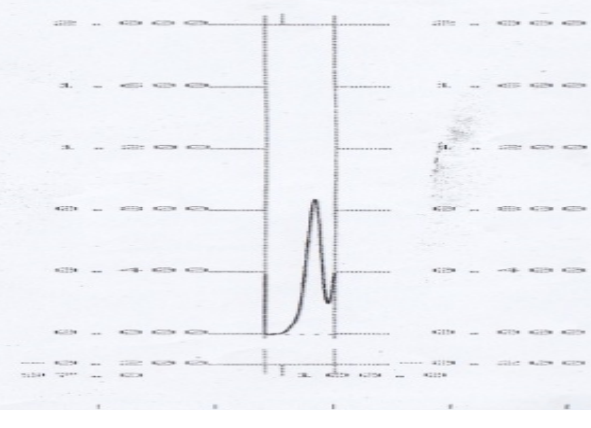

e. Chloroform

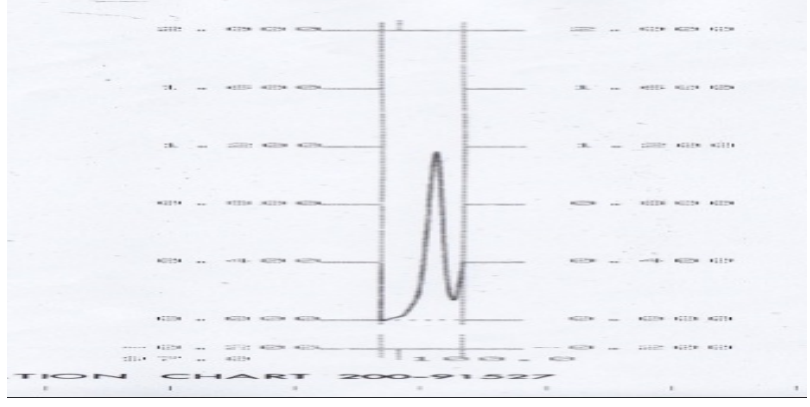

b. Metanol

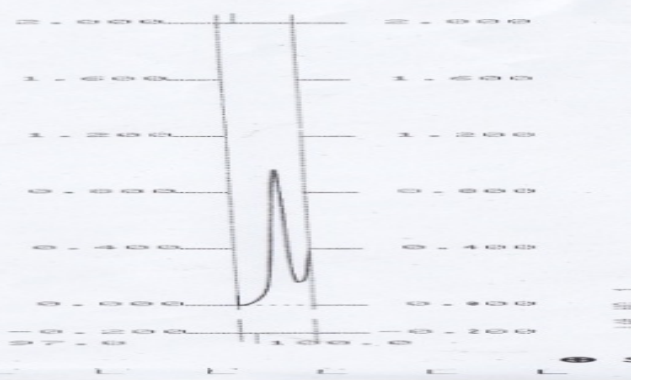

d. Etil asetat

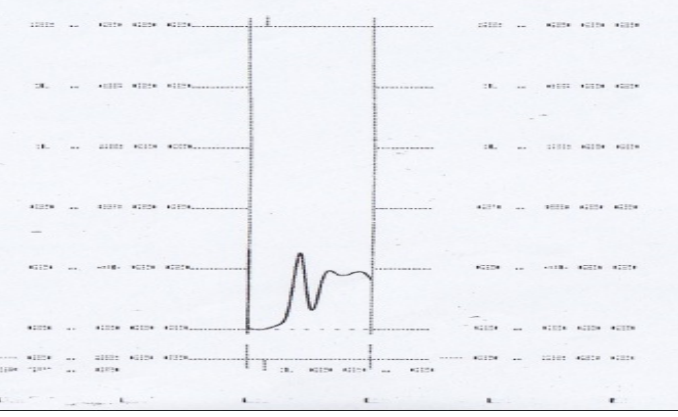

f. Hexane

Gambar 1. Grafik Hasil TLC Densitometri uji pelarut organik

Hasil yang diperoleh dari grafik di atas menunjukkan luas area masing-masing pelarut, di mana pada penelitian ini diperoleh area tertinggi terdapat pada pelarut metanol sebesar 307607,0; etanol sebesar 298597,6; etil asetat sebesar 257751,9; cloroform sebesar 227240,8; dan hexane sebesar 110901,0. Adanya perbedaan luas area pada masing-masing pelarut disebabkan tingkat kelarutan capsaicin terhadap pelarut berbeda-beda. Menurut Purseglove et al., (1981) [10] ekstrak senyawa capsaicin tidak larut dalam air, tetapi larut dalam lemak, metanol, etil asetat, dan etil alkali.

Untuk menentukan kadar capsaicin dari masing-masing pelarut, luas area masingmasing pelarut yang diperoleh dibagi dengan luas area pada kurva standar lalu dikalikan dengan jumlah totolan kurva standar (ug) dibagi jumlah totolan sampel dari masingmasing pelarut (ug). Hasil yang diperoleh merupakan jumlah capsaisin dari masingmasing pelarut, dapat dilihat pada Gambar 2 di bawah ini : 


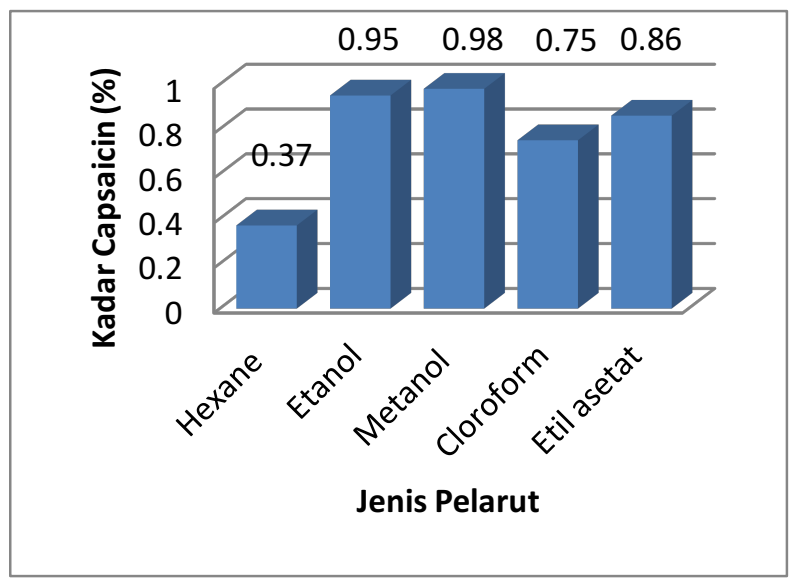

Gambar 2. Jumlah Capsaicin Terhadap Masingmasing Pelarut

Pada grafik di atas dapat dilihat kelarutan capsaicin terbesar pada metanol dan etanol sedangkan terendah terdapat pada hexane. Pada penelitian ini digunakan pelarut etanol untuk melarutkan capsaicin, ini disebabkan karena etanol merupakan alkohol yang dapat melarutkan capsaicin dan juga capsaicin larut dalam pelarut polar karena capsaicin memiliki varietas yang bersifat polar. Menurut pernyataan Pursegglove et al., (1981), capsaicin merupakan alkaloid yang memiliki kelarutan tinggi di dalam alkohol namun rendah di dalam air. Selain itu capsaicin dianggap sebagai minyak dengan sifat lipofiliknya, capsaicin juga larut dalam lemak. Capsaicin memiliki titik leleh pada suhu $62-65{ }^{\circ} \mathrm{C}$ dan titik didih $210-220{ }^{\circ} \mathrm{C}$. Ekstrak senyawa ini tidak berbau, tidak berwarna, dan termasuk dalam golongan non polar yaitu yaitu tidak larut dalam air tapi dapat larut dalam minyak/lemak, metanol, etil asetat dan etil alkali.

\subsection{Penentuan Kadar Capsaicin}

\subsubsection{Cabe bubuk}

Bahan yang dianalisa berupa bubuk cabe katokkon berwarna hijau (masih muda) dan bubuk cabe katokkon berwarna merah (sudah tua). Kadar air bubuk cabe katokkon yang diperoleh sebesar $11,43 \%$ bk untuk cabe katokkon hijau dan 14,15\% bk untuk cabe katokkon merah. Perbedaan kadar air pada kedua sampel uji disebabkan karena tingkat kematangan buah yang berbeda. Makin tua buah maka kadar airnya semakin tinggi. Air yang ada dalam bahan harus diuapkan agar tidak terjadi kesalahan saat analisa dan mempengaruhi hasil akhir pengamatan.

Bubuk cabe katokkon dianalisa dengan menggunakan TLC (Thin Layer Chromatography) di mana hasil penotolan sampel bubuk cabe katokkon dapat dilihat pada Gambar 3 di bawah ini. Hasil yang diperoleh terdapat tiga grafik yaitu grafik standar, grafik cabe katokkon bubuk hijau, dan grafik cabe katokkon merah. Larutan standar capsaicin merupakan pembanding untuk kedua sampel yang akan dianalisa. Dari ketiga grafik diperoleh luas area masing-masing grafik dan dari hasil luas area larutan standar diperoleh persamaan linier yaitu $y=57236 x-16196 \mathrm{di}$ mana $\quad \mathrm{R}^{2}=0,997$. Standar Bubuk cabe hijau

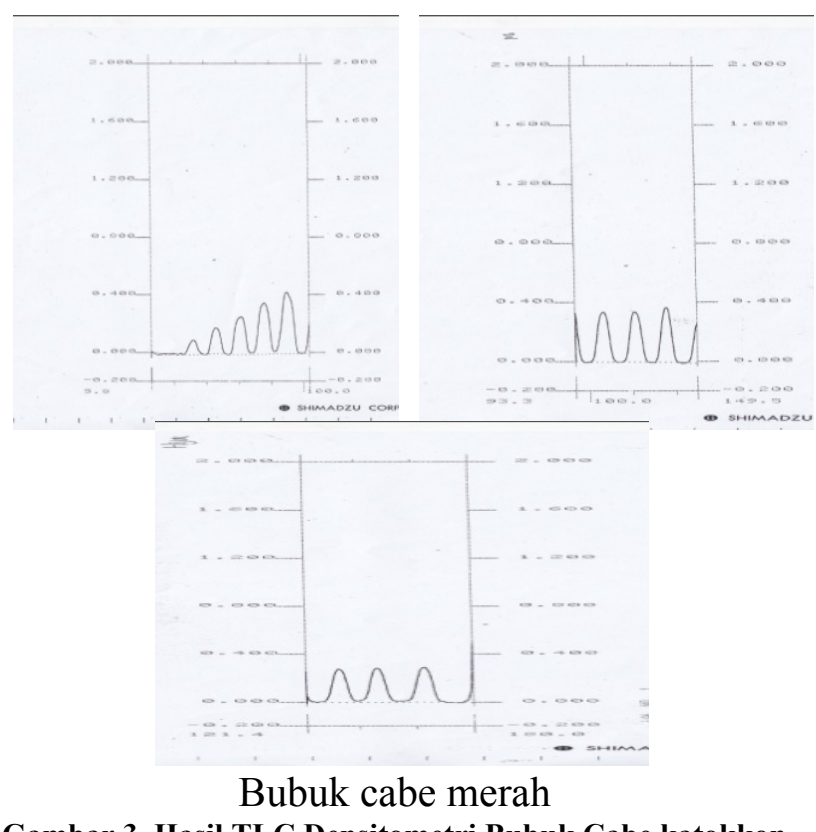

Gambar 3. Hasil TLC Densitometri Bubuk Cabe katokkon

Luas area masing-masing sampel dimasukkan ke dalam persamaan regresi linier kurva standar sehingga dapat dihitung kadar capsaicin dari bubuk hijau dan bubuk merah dari cabe katokkon. Adapun hasil perhitungannya dapat dilihat pada Gambar 4 di bawah ini : 


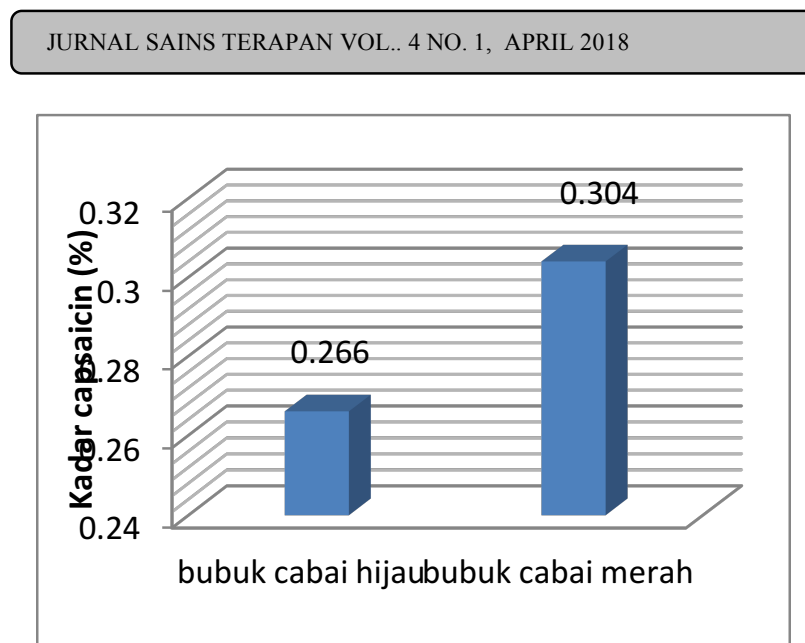

Gambar 4. Jumlah Capsaicin Pada Cabe katokkon Bubuk Hijau dan Merah

Hasil yang diperoleh dari grafik di atas menunjukkan bahwa kadar capsaicin pada bubuk cabe katokkon merah lebih besar dari cabe katokkon bubuk hijau. Pengujian kadar capsaicin dilakukan tiga kali ulangan dan dirata-ratakan pada bubuk cabe katokkon merah sebesar 0,304\% ( $\pm 0,016)$ sedangkan bubuk cabe katokkon hijau sebesar 0,266\% ( \pm 0,015). Ini disebabkan karena kandungan capsaicin dalam cabe berpengaruh terhadap tingkat kematangan buah. Semakin matang buah (merah) maka semakin tinggi kadar capsaicinnya. Hal ini didukung oleh pernyataan Syarma \& Matingor (1975) [11], kandungan capsaicin bervariasi pada jenis dan varietas yang berbeda dan dipengaruhi oleh tingkat kematangan buah cabe. Menurut Lee (1971) [12], selama proses pematangan buah terjadi peningkatan kandungan capsaicin tetapi setelah periode tertentu tidak terjadi sintesis senyawa capsaicin lagi.

\subsubsection{Tingkat Kepedisan (Scoville Heat Unit)}

Tingkat kepedisan cabe berbeda-beda tergantung dari kadar kepedisan cabe tersebut. Pada cabe katokkon diperoleh hasil perhitungan tingkat kepedisan menurut Scoville (1912) dan Weiss (2002) adalah sebagai berikut :

Tabel 1. Total SHV dalam Bubuk Cabe Katokkon
ISSN 2406 - 8810

\begin{tabular}{|c|c|c|c|c|}
\hline Perlakuan & $\begin{array}{c}\text { Tingkat } \\
\text { kematangan }\end{array}$ & $\begin{array}{c}\text { Kadar } \\
\text { capsaicin } \\
(\mathrm{ppm})\end{array}$ & SHV & $\begin{array}{c}\text { Total } \\
\text { SHV }\end{array}$ \\
\hline \multirow{3}{*}{ Bubuk } & Hijau & 2665,493 & 16,1 & 42914,437 \\
\cline { 2 - 5 } & Merah & 3029,7 & 16,1 & 48778,17 \\
\hline
\end{tabular}

Hasil yang diperoleh dari tabel di atas menunjukkan pada bubuk cabe katokkon hijau dan merah berada pada skala 30.000 50.000 SHU di mana skala ini berada pada tingkat yang sangat pedis.Menurut pernyataan Scoville (1912) [7], bahwa kepedasan cabe diukur dalam Scoville Heat Unit (SHU) dan Scoville uji organoleptik digunakan awalnya untuk mengukur SHU. Lima tingkat kepedasan menurut Weiss (2002) [13] diklasifikasikan menggunakan Scoville Panas Unit (SHU).

\section{Kesimpulan}

Kesimpulan yang diperoleh dari penelitian ini sebagai berikut :

1. Pengujian jenis pelarut menggunakan lima jenis pelarut organik yaitu hexane, metanol, etanol, cloroform, dan etil asetat, dan pelarut yang baik dalam melarutkan capsaicin yaitu metanol dengan menggunakan KLT densitometri dengan panjang gelombang 228 .

2. Tingkat kepedisan bubuk cabe katokkon berada dalam skala sangat pedis 30.000 - 50.000 SHU dengan kadar capsaicin pada bubuk cabe katokkon hijau sebesar 2665,493SHU danbubuk cabe katokkon merah sebesar 3029,7SHU.

\section{Saran}

Diperlukan adanya pembanding kadar capsaicin antara bubuk cabe katokkon dengan ekstrak cabe katokkon.

\section{Daftar Pustaka}

[1] Krajewska, M. A., dan Powers, J. J. (1987), "Gas Chromatography of Methyl Derivatives of Naturally Occurring Capsaicinoids", Journal of Chromatography, 409, 223-233. 
[2] Surh, Y.J., (2002). More than spice: capsaicin in hot chili peppers makes tumor cells commit suicide, J. Natl. Cancer Inst. 94: 1263-1265.

[3] Razavi R, Chan Y, Afifiyan FN, Liu XJ, Wan X, Yantha J, (2006). "TRPV1+ sensory neurons control beta cell stress and islet inflammation in autoimmune diabetes." Cell. 15;127(6):1123-35.

[4] Ramachandra Rao, S. \& G.A. Ravishankar. (2002). Plant cell cultures: Chemical factories of secondary metabolites. Biotechnol. Adv. 20: 101-153.

[5] Satyanarayana, M. (2006). Capsaicin and Gastric Ulcers. Critical Reviews in Food Science and Nutrition 46 (4): 275-328.

[6] Vanisree, M., Chen-Yue, L., Shu-Fung., L., Nalawade, S.M.,Lin,C.Y. \& HsinSheng, T. 2004. Studies on the Production of Some Important Secondary Metabolites from Medicinal Plants by Plant Tissue Cultures. Bot. Bull.Acad.Sin. 45: 1-22.

[7] Scoville, W.L., (1912). "Note Capsicum".American Pharmacists Association 1:453.

[8] Sanatombi, K. and G.J. Sharma, 2008. Capsaicin contentand pungency of different capsicum ssp cultivars. Notulae Botanicae Horti Agrobotanici Cluj, 36(2):89-90.

[9] Todd, P.H., M.G. Bensinger and T. Biftu, (1977). Determination of pungency due to capsicum by gasliquid chromatography. J. Chromatogr., 367: 438-442.

[10]Purseglove. J.W., E. G. Brown. C. L. Green \& S. R. J. Robbins. (1981). Spices. Vol. 1. Longman. London \& New York. 331 $-433 p$.
[11] Sharma, H. C. And P. O. Matingor, 1975. Prugent Principles of Chilie. Arecanut and Spices Bull. $6: 78-81$.

[12] Lee, S. W. 1971. Physicochemical Studies on The After Ripening of Hot Pepper Fruits VI. Hot Taste Component in Different Part Capsaicin Homologous. J. Korean Agric. Chem. Soc. 14 : 157-163.

[13] Weiss E.A. 2002. Spice Crops. CABI Publishing International, New York, 2002; 411. 